\title{
RODENTS AS A POTENTIAL SOURCE OF SOME ZOONOTIC ENTERIC PARASITES IN BENI-SUEF PROVINCE
}

\author{
GIHAN, K. ABDEL-LATEF ${ }^{*}$ and LILIAN NAGY MAHROUS ${ }^{* *}$ \\ *Departments of Hygiene, Management and Zoonoses \\ *** Veterinary Parasitology, Faculty of Veterinary Medicine, Beni-Suef University, Beni-Suef 62515, Egypt.
}

\section{ABSTRACT}

Received at: 31/3/2015

Accepted: 25/4/2015
Parasitic infections affecting the world's populations have a global significance. Infections are predominant in underdeveloped agricultural and rural areas of tropical and subtropical regions, causing reduced worker productivity and a waste of economic resources. The current study aimed to investigate epidemiological aspects and the occurrence of some zoonotic enteric parasites in different areas of Beni-Suef province, Egypt. Therefore, a total of 536 human stool samples (149 from diarrheic individuals of different ages and both sexes and 387 from apparently healthy individuals). Moreover, 95 fecal samples from rodents were collected from both rural and urban areas in Beni-Suefprovince for the detection of zoonotic enteric parasites by examination of direct fecal smears and concentration methods using different solutions (Shethear's solution, Zn sulphate and formol ether). Recovered parasites were Paragonimus-like (0.7\%), Hymenolepis nana (12.5\%), Hymenolepis diminuta (0.18\%), Enterobius (7.1\%), Giardia spp. (11\%), Entamoeba histolytica $(16.9 \%)$ and mixed infection with more than one parasite represent $1.7 \%$. Abundance of positive cases show rural residence with both rats and animal contact, with the young age groups were more liable to the infestation than the other groups. Examination of fecal samples from rats revealed infection rates of $33.7 \%$. Hymenolepis diminuta was the most common parasite (20\%) followed by Hymenolepis nana (12.6\%) and Capillaria hepatica (1.05\%).

Keywords: Giardia sp, Entamoeba histolytica, Hymenolepis spp., Rats, zoonoses

\section{INTRODUCTION}

Gastrointestinal protozoon parasites are a major health problem with a high prevalence worldwide (Abd El Bagi et al., 2004). The prevalence of parasitic diseases depends on environmental, social and economic factors to such an extent that the presence of intestinal parasites is an indicator of vast collective ill health. In Egypt, clinical and economic impacts of parasitic zoonoses have been reported by several researchers. School-age children are prone to intestinal parasites because of crowding and behavioral patterns that greatly contribute to the spread of parasitic infection. A high prevalence of parasitic infection in children has been recorded, with levels reaching up to $48 \%$ (Banta et al., 1964). In addition, parasitic diseases are prevalent among the residents of rural areas. Previous literature of parasitic infections performed on villages revealed high infection rates of single and multiple gastrointestinal parasitic infections (85\%) in small villages (Banta et al., 2009; Fawzi et al., 2004). Parasitic diseases pose serious public health effects on both immunocompromised and immunocompetent patients (Baiomy et al., 2010; Abdel-Hafeez et al., 2012). Moreover, parasites are considered to be the mainetiologic agent of diarrhea, with prevalence $61 \%$ among individuals suffering diarrhea (El-Naggar et al., 2006; Mousa et al., 2010). In a survey conducted in the Delta region, $67.1 \%$ of chronic diarrheic patients were found suffering from parasitic infections. In such work, single infection $(54.2 \%$ of all patients) and mixed infections (12.9\% of total chronic diarrhea patients) were present (Baiomy et al., 2010).

During the last decades, the presence of Giardia sp. and Entamoeba spp. in the environment, especially 
water, and in mammals, including humans, has been raised (Tavarez et al., 1991; Fayer et al., 2000). Giardiasis is a major diarrheal disease found worldwide. It has been found that animals are considered as reservoirs for Giardia sp., with $G$. intestinalis could be detected in wild rats (AbdelWahed et al., 1999). Many literatures reported that amoebiasis is the most aggressive protozoal disease that affects the human bowel and is considered as a mandatory cause of death among the parasitic diseases (WHO, 1997). Amoebiasis is a global protozoal disease, with approximately 50 million people are infected annually, with the end result of 100,000 deaths (WHO, 1997; Gatti et al., 2002). It is thought to be more common in areas of poor sanitation and nutrition, particularly in the tropics (Gatti et al., 2002). Zoonotic transmission of $E$. histolytica has been discussed by Jackson et al. (1984). Experimental infection with E. histolytica occurred in dogs, cats, rats, monkeys and other laboratory animals. These animals might be infected with human strains as a result of close contact with humans. Hymenolepis diminuta infection in humans is uncommon (Levi et al., 1987; Hamrick et al., 1990; Varghese, 1998); with few hundred cases have been reported (Tesjaroen et al., 1987; Lo et al., 1989). $H$. nana is more commonly detected as a cause of human infection since its transmission does not require intermediate host, so it can be directly spread from infected person to another.

Paragonimiasis is a cosmopolitan in many parts of Africa, Asia and South America (Gary, 2009). In humans, infection occurs by ingestion of raw or undercooked freshwater crabs or crayfishes (Singh et al., 2005). Capillaria hepatica, the causative agent of hepatic capillariasis, mainly affects rats and is rarely seen in man. Pinworms spread through humanto-human transmission, by fecal-oral route (Burkhart and Burkhart 2005).

Household pets often carry eggs in their fur, while infection by this route is not recorded yet (Wolfe 1978).

Rats act as reservoir host for many zoonotic pathogens including parasites that pose a health risk to humans (Paramasvaran et al., 2009). Several helminthes parasites are common in both man and rodents. Some are accidentally infect and have a little public health importance, while others naturally occur in rodents and play a significant role in the prevalence of some of human parasites (Flynn, 1973).
The current work aimed to detect the prevalence of different zoonotic parasites infecting humans and rats in different localities of Beni-Suef province, Egypt with determination of the role of rats in transmission of such zoonotic parasites among human beings.

\section{MATERIALS and METHODS}

\subsection{Rat fecal samples:}

A total of 95 fecal samples were collected from rats from different areas in Beni-Suef province (coordinates: $29^{\circ} 04^{\prime} \mathrm{N} 31^{\circ} 05^{\prime} \mathrm{E}$ ), Egypt. Each sample was put into individual plastic container and was transferred to the Laboratory of Parasitology, Faculty of Veterinary Medicine, Beni-Suef University and stored at $4^{\circ} \mathrm{C}$ for parasitological examination.

\subsection{Human stool samples:}

Human stool samples were collected from nearby hospitals from Beni-Suef province and from outpatients admitted to clinics. Accordingly, a total of 536 samples were collected. Data of patients were recorded for each sample (residence, age, sex, consistency of the stool,... etc). According to age grouping, patients were classified into 5 groups, each of 10 years interval and beginning from the old of one year. Samples were collected in accordance with WHO guidelines of collection of fecal samples (WHO 1991). Each sample was labelled and sent to the laboratory for further parasitological examination.

\section{Laboratory procedures}

\subsection{Macroscopic examination:}

All fecal samples were visually examined by naked eyes to detect adult nematodes and proglottides of tapeworm.

\subsection{Floatation and sedimentation techniques:}

Each sample was subjected to fecal floatation technique using different solutions (saturated salt solution, zinc sulphate solution and Sheather's solution) according to Zajac and Conboy (2006). Furthermore, formol ether sedimentation technique was applied for each sample (Lee et al., 2010). Lugol's iodine solution was used to facilitate identification of protozoal cysts and trophozoites. Parasite eggs/oocysts were identified based on color, shape and contents according to the key given by Soulsby (1982) and examined by light microscopy using different magnifications. 


\section{RESULTS}

Table 1: Distribution patterns of enteroparasitic stages recovered from patients in different localities in BeniSuef province, Egypt.

\begin{tabular}{|c|c|c|c|c|c|c|c|c|c|c|c|c|c|}
\hline \multirow[b]{2}{*}{ Parasite } & \multirow[t]{2}{*}{ Age } & \multicolumn{2}{|c|}{$1-10 y$} & \multicolumn{2}{|c|}{$11-20 y$} & \multicolumn{2}{|c|}{$21-30 y$} & \multicolumn{2}{|c|}{$31-40 y$} & \multicolumn{2}{|c|}{ More than $40 \mathrm{y}$} & \multicolumn{2}{|c|}{ Total } \\
\hline & & $\hat{\delta}$ & q & 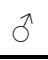 & q & 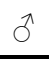 & q & 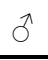 & 우 & $\pi$ & q & No. & $\%$ \\
\hline \multirow{6}{*}{$\begin{array}{l}\text { Single } \\
\text { infection }\end{array}$} & Paragonimus-like & 1 & 0 & 1 & 0 & 0 & 0 & 1 & 1 & 0 & 0 & 4 & 0.7 \\
\hline & Hymenolepis nana & 15 & 18 & 9 & 8 & 4 & 5 & 2 & 5 & 1 & 0 & 67 & 12.5 \\
\hline & H. diminuta & 0 & 0 & 1 & 0 & 0 & 0 & 0 & 0 & 0 & 0 & 1 & 0.18 \\
\hline & Enterobius & 7 & 15 & 9 & 5 & 0 & 2 & 0 & 0 & 0 & 0 & 38 & 7.1 \\
\hline & Giardia spp. & 12 & 15 & 13 & 10 & 1 & 5 & 1 & 1 & 1 & 0 & 59 & 11 \\
\hline & Entamoeba histolytica & 23 & 13 & 7 & 9 & 7 & 14 & 9 & 2 & 5 & 2 & 91 & 16.9 \\
\hline \multicolumn{2}{|c|}{ *Mixed infection } & 4 & 3 & 0 & 2 & 0 & 0 & 0 & 0 & 0 & 0 & 9 & 1.7 \\
\hline \multicolumn{2}{|r|}{ Negative } & 63 & 34 & 15 & 17 & 27 & 16 & 21 & 7 & 33 & 34 & 267 & 49.8 \\
\hline
\end{tabular}

*Mixed infection with Hymenolepis nana \& Entamoeba histolytica found in 7 (1.3\%), Hymenolepis nana, Enterobius \& Entamoeba histolytica in 1(0.18\%) and Enterobius and Entamoeba histolytica in 1 (0.18\%).

Table 2: incidence of enteric parasite in examined rats.

\begin{tabular}{cccc}
\hline Parasite & Examined No. & Infected No. & Percentage of infection \\
\hline Hymenolepis nana & 95 & 12 & 12.6 \\
\hline Hymenolepis diminuta & 95 & 19 & 20 \\
\hline Capillaria hepatica & 95 & 1 & 1.05 \\
\hline Total & 95 & 32 & 33.7 \\
\hline
\end{tabular}

\section{DISCUSSION}

Light microscopic examination of randomly selected fecal samples obtained from patients revealed the presence of multiple parasitic infections including species belonging to trematoda, cestoda, nematode and protozoa. Among trematodes, Paragonimus-like digenean was found only in four $(0.7 \%)$ patients. This finding is consistent with that obtained by Nworie et al. (2013) who found a prevalence rate of $0.78 \%$ (7 out of 900 stool samples) in Ebonyi, Nigeria. They attributed the low prevalence to the fact that paragonimiasis is a lung infection and eggs are expected to be highly found in sputum not in stool samples. Meanwhile, in few cases, swallowing of sputum may probably give rise to the occurrence of few eggs could be observed in stool samples. The present study revealed that there were no significant differences of infections rates between males and females. Previous literature reported that there were no sex- related differences in prevalence rates (Uchiyama et al., 1999; Ashitani et al., 2000). On the other hand, Nworie et al. (2013) found that infection rate in males was significantly higher $(11.11 \%)$ than females $(5.19 \%) \quad(P \leq 0.05)$. Likewise with data obtained by Singh et al. (1986); Udonsi (1987); Uttah et al. (2013) who found that males are more infected than females. This opinion opposed the results of Ibenga et al. (1997); Asor et al. (2003); Uttah et al. (2013) who determined that infection rates were significantly higher in females than males. It is worthy to mention that, although both sexes can acquire the infection through food, males encounter crabs more than females.

The current work revealed that Hymenolepis nana was found in $67(12.5 \%)$ examined human stool samples. $H$. nana, the dwarf tapeworm infecting humans, was the second most prevalent cestodal worm detected in this study. Most infected patients were children aged one to 10 years. Mild infections usually passed asymptomatic. In severe infection patients suffered from headache, dizziness, purities, diarrhea, restlessness or even convulsion (Sun, 1988). Lower infection rate by $H$. nana was recorded in Baghdad by Alia and Afkar (2009) (1.8\%). Khalaf et al. (1979) in Egypt found that out of 471 stools samples obtained from patients suffering from 
gastrointestinal disease, $62.6 \%$ had ova of $H$. nana in their stools. Moreover, Jassim et al. (1986) estimated infection rate of $8 \%$ in Kirkuk city. In the authors' opinion, the considerably higher infection rate in the present investigation might be related to the habits of wandering outdoors with neglected personal hygiene as well consuming foods from outdoor vendors whom may be carrier of some parasites with high possibilities to human transmission. The present findings revealed one $(0.18 \%)$ positive sample for Hymenolepis diminuta in accordance with Daniel (1998) who found one case of $H$. diminuta infection in a child from Guadalajara, Spainand Massimo et al. (2003) in Italy who reported a case of H.diminuta infection in an Italian child. Other studies recorded infection rate ranging between 5.5 and 0.001 Panpiglione et al. (1987) and Mercado and Arias (1995), respectively. Human infection with $H$. diminuta is rather uncommon due to the accidental mode of transmission by swallowing of rat fleas which contains the infective cysticercoids. Our study exhibited investigation rate of $7.1 \%$ for pinworms. This prevalence is lower than the results obtained by Rafique et al. (2009) who found Enterobius spp. in $76 \%$ of human stool samples. On the other hand, lower infection ratewas obtained by Khalaf et al. (1979) as Enterobius was detected in 5.8\% ofexaminedstool samples. Pinworms infection are often less dangerous but remain one of the most common parasitic nematodes seen by the family physician, particularly prevalent in the pediatric age group, but less in adults. In both groups, the most common symptoms wereanal purities. These helminths were also found in GIT contents of commensal rats and mice (Flynn 1973 and Ceruti et al., 2001).

Microscopic examination showed infection rate of 11 $\%$ for Giardia spp. Higher infection rates (44\%) were recorded in Egypt by Zaki et al. (1986) and 44.1\%in the aborigine community in Pahang, Malaysia by Noor et al. (2007). Yakubu and Sathiakumar (1985) in Nigeria donated that Giardia lamblia represented $41 \%$ of the enteropathogenic agents identified in patients stool samples. In Amman, Jordan Shakkoury and Wandy (2005) recorded infection rate of $78 \%$ among the examined children. Even lower prevalence has been reported by other authors in different areasas in Kumasi, Ghana $(11.0 \%)$ by Addy and Aikins (1986) and in Gaza, Palestine $(10.3 \%)$ by Al-Hindi and El-Kichaoi (2008). Results exhibited that the age groups 1-10 and 11-20 years showed higher incidence rates. Wongjindanon et al. (2005); Ayeh et al. (2009); Nyarango et al. (2008) explained that the nature of everyday activities exposing people, particularly children, to be contact with natural sources of contamination such as soil and water, with consequent increase of their risk to infection with parasites.
The present study revealed infection rate for E. histolytica/dispar $16 \%$ in the age group 1-10 years and the incidence was higher in males than females. Lower percentages have been reported by Inabo et al. (2000) in Northern Nigeria, conducting that the prevalence of $E$. histolytica in primary school pupils in five villages in Kaduna and Zaria districts were $8.55 \%$. Regarding to age, it has beennoted that 5-9 years age group was prone to the infection than the 10-15 years group. Moreover, in Makkah, Saudi Arabia, a prevalence rate of $2.6 \%$ was reported by Saeed and Manal (2007). Higher incidence was recorded by Yakubu and Sathiakumar (1985) in Nigeria. Theyobserved that enteropathogenic agents were identified in stools of $26(23 \%)$ patients representing E. histolytica. Aza et al. (2003) in Malaysia reported that the prevalence of E. histolytica was 21\%.Meanwhile, Obadiah (2012) found that 72 $(37.9 \%)$ were positive for $E$. histolytica in stool samples. The age groups mostly infected were 0-9 years, and most cases were significantly associated with diarrhea. Zoonotic transmission of E. histolytica has been suggested by Jackson et al. (1984). Experimental infections with $E$. histolytica have been done in dogs, cats, rats, monkeys and other laboratory animals. Previous literature determined the presence of E. histolytica in wild rats. Among those, Fagir and El-Rayah (2009) in Sudan; Tung et al. (2009) in Taiwan, and Paramasvaran et al. (2009) in Malaysia. Krishnasamy et al. (1980) in Malaysia reported the protozoan in the wood rat. These animals might acquire human strains as a result of the close contact with humans. Amoebiasis is an invasive protozoal infection caused by Entamoeba histolytica (WHO, 1997), and considered the most aggressive protozoal disease that affects the human bowel and incriminatedin some deaths. Among the parasitic diseases, Amoebiasisare worldwide, with approximately 50 million people infected annually, causing close to 100,000 deaths (WHO, 1997 and Gatti et al., 2002). It is said to be more common in areas of poor sanitation and nutrition, particularly in the tropics (Gatti et al., 2002).

Rats are highly adaptable to many environments throughout the world. Unfortunately they act as reservoir host for many zoonotic pathogens including parasites that pose a health risk to humans (Paramasvaran et al., 2009). Several species of helminthes parasites are common to both man and rodents. From which some are accidentally infect humans and are of minor public health importance; while the others play a significant role in human diseases (Flynn, 1973).

Our examination of fecal samples obtained from rats as shown in table (2) revealed the presence of multiple parasitic stages belonging to cestoda and nematode. The results exhibited infection rate of $12.6 \%, 20 \%$, and $1.05 \%$, for Hymenolepis nana, 
Hymenolepis diminuta and Capillaria hepatica respectively with overall prevalence of $33.7 \%$. This result is lower than that obtained by Tung et al. (2009) who found that the overall prevalence of parasitesin rodents from different localities in Taichung, Taiwan was $93.7 \%$.

From the result it was obvious that $H$. nana and $H$. diminuta were the common parasites in examined rodents with $H$. diminuta is the most prevalent one. The results are nearly in agreement with Webster and MacDonald (1995) who found that $22 \% \mathrm{H}$. diminuta eggs in 225 examined rats in one farm in UK. Furthermore Easterbrook et al. (2008) recorded that Hymenolepis diminuta represent (34.4\%) in 162 examined rats in Baltimore, Maryland, USA. Moreover Mohd Zain (2008) stated that $H$. diminuta represented $(35 \%)$ in two urban rat populations in Kuala Lumpur, Malaysia.

Lower percentage of $\mathrm{H}$. nana (11\%) recovery recorded by Webster and MacDonald (1995) in the rats they examined. In contrast higher percentage (48\%) was detected by Rafeique et al. (2009) in wild rodents in Pakistan. Moreover Gilioli et al. (2000) and Mohd Zain (2008) stated that $H$. nana represented $40 \%$ and $28.4 \%$ in rats they examined.

Hymenolepis species are tapeworms occurring throughout the world. Over 400 species are found in higher vertebrates, while the definitive hosts are rodents (Little and Ambrose, 2000 and Bahadir, 2002). It is the most notorious for causing pathologic effect of public health importance (Ceruti et al., 2001). $H$. nana and $H$. diminuta are the two most problematic for humans. Although H. nana is mainly a parasite of humans, but it is found more commonly in rats and mice, and has been widely used as a model system for the study of cestode tape worm biology (Ito and Itagaki, 2003) H. nana is a zoonotic parasite and is common in children and institutionalized groups (Rauch, 1993 and Alvez et al., 2003). H. diminuta has also been reported among rats in Belgrade (Kataranovski et al., 2011), Sudan (Fagir and El-Rayah, 2009), Baltimore, USA (Easterbrook et al., 2008), in the city of Doha, Qatar (Abu-Madi et al., 2001), Nigeria (Mafiana et al., 1997), Kuala Lumpur, Malaysia (Leong et al.,1979) and peninsula Malaysia (Krishnasamy et al., 1980). Man acquires the infection via ingestion of infected intermediate host. Its infection may cause diarrhea or occasionally cachexia in man (Sun, 1988).

Capillaria hepatica, reported in this study was also reported among rats in Belgrade (Kataranovski et al., 2011), Taiwan, (Tung et al., 2009), and Malaysia (Paramasvaran et al., 2009). Moreover Elshazly et al. (2008) studied the prevalence of helminths in rodents in Egypt. The overall prevalence of helminths was 52.8\%. The commonest cestode detected was $H$. diminuta and the commonest nematode detected was Capillaria hepatica. Siti et al. (2012) found that out of 137 samples among wild rats in urban area of Kuala Lumpur, Malaysia, $81.8 \%$ samples were positive with intestinal parasites .Six different parasites were detected. The most common intestinal helminth parasite detected was Hymenolepis nana (23.4\%), Capillaria hepatica (13.9\%) and Hymenolepis diminuta (2.9\%).

Capillaria hepatica is a very rare zoonotic infection which primarily infects rodents and is rarely found in humans. Infection manifested by fever of unknown origin and hepatomegaly peripheral eosinophilia.

From the results it is clear the high prevalence of parasitic infection in rats exhibiting no signs in rats except in heavy infection (Tanaka et al.,1974; Baker, 1998). The study throw light on the role of rodents in the spread of enteric parasite in environment and the need for application of appropriate control measures to prevent the human disease transmission.

\section{CONCLUSION}

Rats being closely associated with humans and may harbors many different kinds of intestinalparasites serving as great potential for zoonotic infections to man. These rodentscan serve as a source of human infection especially with poor environmental/hygienic conditionsso control of rats is of prime importance in the prevention and control of zoonotic infections in man. The continuous increasing in the amount of garbage collected contributes high rat prevalence. Close proximity of man with rats as well contributing significantly in the increase of zoonotic disease spread.

\section{REFERENCES}

AbdEl Bagi, M.E.; Sammak, B.M.; Mohamed, A.E.; Al Karawi, M.A.; Al Shahed, $M$. and $A l$ Thagafi, M.A. (2004): Gastrointistinal parasite infection. EurRadiol ,14: E116-E131.

Abdel-Hafeez, E.H.; Ahmad, A.K.; Ali, B.A. and Moslam, F.A. (2012): Opportunistic parasites among immunosuppressed children in Minia District, Egypt. Korean J. Parasitol 50:57-62.

Abd el-wahed, M.; Salem, G.H. and El-Assaly, T.M. (1999): The role of wild rats as a reservoir of some internal parasites in Qalyobia governorate. Journal of the Egyptian Society of Parasitology, 29:495-503.

Abu-Madi, M.A.; Lewis, J.W.; Mikhail, M.; ElNagger, M.E. and Behnke, J.M. (2001): Monospecific helminthes and arthropod infection in an urban population of brown rats from Doha, Qatar.J.Helminthol., 75: 313-320. 
Addy, P.A. and Aikins, B.P. (1986): Cryptosporidiosis in diarrhoeal children in Kumasi, Ghana. Lancet., 1(8483):735

Al-Hindi, AI. and El-Kichaoi, A. (2008): Occurrence of gastrointestinal parasites among pre-school children, Gaza, Palestine. The Islamic University Journal (Series of Natural Studies and Engineering, 16(1): 125-130.

Alia, Y.Y. and Afkar, M.H. (2009): Prevalence of Hymenolepis nana in children in Baghdad-AlResafa. Iraqi Journal of Veterinary Medicine Vol. 33, No. 2, 158

Alvez, J.R.; Macedo, H.W.; Ramos, A.N.; Ferreira, L.F.; Goncalves, M.L. and Araujo, A. (2003): Intestinal parasite infections in a semiarid area of Northeast Brazil: Preliminary findings differ from expected prevalence rates. Cad Saude Publica., 19 (2): 667-670.

Ashitani, J.I.; Kumamoto, K. and Matsukura, S. (2000): Paragonimiasiswestermani with multifocal lesions in lungs and skin. Internal Med., 39: 433-436.

Asor, J.E.; Ibang, E.S. and Arene, F.O.I. (2003): Paragonimusuterrobilateralis: Peak period of egg output in sputum of infected subjects in Cross River Basin, Nigeria. Mary Slessor J. Med., 3: 24-27.

Ayeh-Kumi, P.F.; Quarcoo, S.; Kwakye-Nuako, G.; Kretchy, J.P.; Osafo-Kantanka, A. and Mortu, S. (2009): Prevalence of Intestinal Parasitic Infections among Food Vendors in Accra, Ghana. J. Trop. Med. Parasitol, 32(1):1.

Aza, N.; Ashley, S. and Albert, J. (2003): Parasitic Infection in Human Communities Living on the Fingers of the Crocker range park, Sabah, Malaysia. ASEAN Review of Biodiversity and Enviromental Conservation (ARBEC). http: // hwww.arbec.com.my/pdf/art II.

Bahadir, G.N. (2002): Analysis of the crude antigen of Hymenolepis nana from mice by SDSPAGE and the determination of specific antigens in protein structure by western blotting. Turk J. Vet. Anim. Sci., 26: 1067-1071.

Baiomy, A.M.; Mohamed, K.A.; Ghannam, M.A.; Shahat, S.A. and Al-Saadawy, A.S. (2010): Opportunistic parasitic infection among immmunocompromised Egyptian patients. J. Egypt Soc Parasitol, 40: 797-808.

Baker, D.G. (1998): Natural pathogens of laboratory mice, rats, and rabbits and their effects on research. Clin. Microbiol. Rev., 11: 231-266.

Banta, J.E.; Akers, T.G.; Arm, H.G. and Freeman, N.L. (1964): An Epidemiologic Study of diarrhea in an alien population in Cairo, Egypt. Am. J. Public. Health Nations Health, 54: 940-946.

Banta, J.E.; Arafa, N.A.; Ahmed, M.A.; Mostafa, M.H. and Mohamed, M.K. (2009): Prevelance of intestinal parasitosis in a rural population in
Egypt, and its relation to socio-demographic characteristics. J. Egypt SocParasitol, 39: 371-381.

Burkhart, C.N. and Burkhart, C.G. (2005): Assessment of frequency, transmission, and genitourinary complications of entrobiasis (pin worm0. International journal of Dermatology 44(10): 837-840.

Ceruti, R.; Sonzongi, O.; Origgi, F.; Vezzoli, F.; Cammarata, S.; Guisti, A.M. and Scanziani, E. (2001): Capilaria hepatica infection in wild brown rat (Rattusnorvegicus) from the urban area of Milan, Italy. J. Vet. Med. 48: 235-240.

Daniel, T.; Simon, M.P.; Gimeno, C.; Pomata, M.T.P.; Illescas, S.; Amondarain, I.; Gonzalez, A.; Dominguez, J. and Bisquert, J. (1998): Human Infection with Hymenolepisdiminuta: Case Report from spain. J. Clin. Microbiol., 36(8): 2375-2376.

El-Naggar, S.M.; El-Bahy, M.M.; AbdElaziz, J. and El-Dardiry, M.A. (2006): Detection of protozoal parasites in stool of diarrhoeic patients using different techniques. J. Egypt Soc Parasitol, 36: 487-516.

Elshazly, A.M.; Awad, S.I.; Azab, M.S.; Elsheikha, H.M.; Abdel-Gawad, A.G.; Khali, H.H. and Morsy, T.A. (2008): Helminthes of synanthropic rodents from Dakalia and Menoufia, Egypt. Journal of the Egyptian Society of Parasitology 38 (3): 727-740.

Esterbrook, J.D.; Kaplan, J.B.; Glass, G.E.; Watson, J. and Klein, S.L. (2008): A survey of rodentborne pathogens carried by wild-caught Norway rats: a potential threat to laboratory rodent colonies. Laboratory Animals 42(1): 92-98.

Fagir, D.M. and El-Rayahel, A. (2009): Parasites of Nile rat in rural and urban region of Sudan. Integrative Zoology 4 (2): 179-187.

Fawzi, M.; El-Sahn, A.A.; Ibrahim, H.F. and Shehata, A.I. (2004): Vegetable -transmitted parasites among inhabitants of El-Prince, Alexandria and its relation to housewives knowledge and practices. J. Egypt Public Health Assoc, 79: 13-29.

Fayer, A.; Trout, J.M.; Graczyk, T.K. and Lewis, E.J. (2000): Prevalence of Cryptosporidium, Giardia and Eimeria infection in post weaned and adult cattle on three Mary land farms. Vet. Parasitol., 93: 103-112.

Flynn, R.J. (1973): Parasite of Laboratory Animals. The Lowa State University Press. Ames, Lowa, USA, pp: 155-157.

Gary W. Procop (2009): North American Paragonemiasis in the contxt of Global Paragonemiasis. ClinMicrobiol Rev. 2009 Jul; 22 (3): 415-446.

Gatti, S.; Swierczynski, G.I.; Robinson, F.; Anselmi, M.; Corrales, J. and Moreira, J. (2002): Amebic infection due to the 
Entamoebahistolytica/dispar complex: a study of the incidence in a remote rural area of Ecuador. American Journal of Tropical Medicine and Hygiene, 67(1): 123-127.

Gilioli, R.; Andrade, L.A.G.; Passos, L.A.C.; Silva, F.A.; Rodrigues, D.M. and Guaraldo, A.M.A. (2000): Parasite survey in mouse and rat colonies of Brazilian laboratory animal houses kept under different sanitary barrier conditions. Arq. Bras. Med. Vet. Zootec. 52 (1): 1327-1334.

Hamrick, H.J.; Bowdre, J.H. and Chrurch, S.M. (1990): Rat tapeworm: Hymenolepisdiminuta infection in a child. Pediatr. Infec. Dis. J. 9: 216-219.

Ibenga, E.S.; Arene, F.O.I. and Asor, J.E. (1997): Association of pulmonary paragonimiasis with active pulmonary tuberculosis in rural yakurr community in cross river basin, Nigeria. Mary Slessor J. Med., 3: 19-21.

Inabo, H.; Galadima, M.; Ogbadu, L.I. and Okuofu, C.A. (2000): $\quad$ Prevelance of Entamoebahistolytica and Giardia lamblia in primary school pupils in five rural villages around Kaduna and Zairia, Nigeria. The Nigerian journal of parasitology, 21: 61-67.

Ito, M. and Itagaki, T. (2003): Survey on wild rodents for endoparasites in Iwate prefecture, Japan. J. Vet. Med. Sci. 65 (10): 1151-1153.

Jackson, T.F.; Anderson, C.B. and Simjee, A.E. (1984): Serological differentiation between past and present infections in hepatic amoebiasis. Transaction of Royal Society of tropical Medecine and Hygiene 78: 342-345.

Jassim, B.A.; Al-Dujaily, A.A. and Saleh, M.H. (1986): Prevalcnce of intestinal parasites in school children of Kirkuk city, Iraq. J. Biol. Sci. Res. 17(16): ! 19-125.

Kataranovski, M.; Mirkov, I.; Belij, S.; Popov, A.; Petrovic, Z.; Gaci, Z. and Kataranoveski, M. (2011): Intestinal helminthes infection of rats (Rattusnorvegicus) in the Belgrade area (Serbia): the effect of sex, age and habitat. Parasite (Paris, France) 18 (2): 18-196.

Khalaf, M.A.; Khalifa, R.; AbdelTawab, A.; AlAnsary, G.H.H. and Abel Kader, M.M. (1979): Phlyctenular eye disease in association with Hymenolepis nana in Egypt. British Journal of Ophthalmology, 1979, 63, 627-631.

Krishnasamy, M.; Singh, K.I.; Ambu, S. and Ramachandran, $\quad$ P. (1980): $\quad$ Seasonal prevalence of the helminth fauna of the wood rat, Rattustiomanicus (Miller) in West Malaysia. Folia Parasitol, 27: 231-235.

Lee, S.H.; Joung, M.; Yoon, S.; Choi, K.; Park, W.Y. and Yu, J.R. (2010): Multiplex-PCR detection of waterborne intestinal protozoa; Microsporidia, Cyclospora and Cryptosporidium. Korean J. Parasitol. 48, 297.
Leong, T.S.; Lim, B.L.; Yap, L.F. and Krishnasamy, M. (1979): Parasitic fauna of the house rat Rattusrattusdiardii in Kuala Lumpor and nearby villages. Southeast Asian Journal of Tropical Medecine and public Health 10, 122-126.

Levi, M.H.; Raucher, B.G.; Teicher, E.; Sheehan, D.J. and McKitrick, J.C. (1987): Hymenolepisdiminutum: one of three pathogens isolated from children. Diagn. Microbiol. Infect. Dis. 7: 255-259.

Little, S. and Ambrose, D. (2000): Spirometrainfection in cats and dogs. Compendium on Continuing Education for the Practising Veterinarian 22: 299-303.

Lo, C.T.; Ayele, Y. and Birrie, H. (1989): Helminth and snail survey in Harerge region of Ethiopia with special reference to schistosomiasis. Ethiopian Medical journal 27: 73-83.

Mafiana, C.; Osho, M. and Sam-Wobo, S. (1997): Gastrointestinal helminth parasite of the black rat (rattusrattus) in Abeokuta, southwest Nigeria. Journal of Helminthology 71 (3): 217-220.

Massimo Marangi, M.; Zechini, B.; Fileti, A.; Quaranta, G. and Aceti, A. (2003): Hymenolepisdiminuta Infection in a Child Living in the Urban Area of Rome, Italy. Italy. J. Clin. Microbiol. 3994-3995

Mercado, R. and Arias, B. (1995): Infeccionespor Taeniasp y otroscestodosintestinales en pacientes de consultoriosyhospitalespublicosdel Sector Norte de Santiago de Chile (1985-1995). Boletin Chileno de Parasitologia 50: 80-83

Mohd Zain, S.N. (2008): Endoparasites of rodents in two islands of the Straits of Malacca. Malay J Sci, 27: 123-127.

Mousa, K.M.; Abdel-Tawab, A.H.; Khalil, H.H. and El-Hussieny, N.A. (2010): Diarrhea due to parasites particularly Cryptosporidium parvum in great Cairo, Egypt. J. Egypt Soc. Parasitol, 40: 439-450.

Noor Azian, MY.; San, YM.; Gan, CC.; Yusri, MY.; Nurulsyamzawaty, $\quad$ Y.; Zuhaizam, AH.; Maslawaty, MN.; Norparina, I. and Vythilingam, I. (2007): Prevalence of intestinal protozoa in an aborigine community in Pahang, Malaysia. Trop Biomed., 24: 55-62.

Nworie, O.; Onyeagba, R.A.; Anyim, C.; Eda, O.E.; Okoli, C.S.; Orji, I.; Okonkwo, E.C.; Ekuma, U.O. and Agah, M.V. (2013): Prevelance of Paragonimusinfection. American Journal of Infectious Diseases 9 (1): 17-23.

Nyarango, R.M.; Ewk, P.A.A. and BO, N. (2008): The risk of pathogenic intestinal parasite infections in Kisii Municipality, Kenya. BMC Public Health., 8: 237.

Obadiah, H.I. (2012): Review of the survey of Entamoebahistolytica in Children; a Brief 
Focus on Nigeria Situation: a Review. J. Phys Pharm Adv, 2(3): 150-157

Panpiglione, S.; Visconti, S. and Pezzino, G. (1987): Human intestinal parasites in Subsaharan Africa. Sao Tome and Principe. Parasitologia 29: $15-25$.

Paramasvaran, S.; Sani, R.A.; Hassan, L.; Kaur, H.; Krishnasamy, M.; Jeffery, J.; Raj, S.; Mohd Ghazali, S. and Hock, L.K. (2009): Endoparasite fauna of rodents caught in five wet in Kuala Lumpur and its potential zoonotic implications. Tropical Biomedicine 26(1): 67-72.

Rafique, A.; Rana, S.; Akhan, HA. and Sohail, A. (2009): Prevalence of Some Helminths in Rodents Captured from Different City Structures including Poultry Farms and Human Population of Fai salabad, Pakistan. Pakistan Vet. J., 29(3): 141-144.

Rauch, R. (1993): The biology of Echinococcus. In Compendium on Cystic Hydatid Disease with special reference to the Xinjiang Uygur Autonomous region, the people's Republic of China (Andersen, F. L., Ed.). pp. 27-56. provo: Brigham Young University Print Services.

Saeed, A.A. and Manal, B.J. (2007): Diagnosis and differentiation of Entamoeba infection in Makkah Al Mukarramah using microscopy and stool antigen detection kits. World journal of Medical Science, 2(1): 15-20.

Shakkoury, W.A. and Wandy E.A. (2005): Prevalence of Giardialamblia infection in Amman, Jordan. Pak. J. Med. Sci., 21(2): 199-201.

Singh, T.S.; Mutum, S.S. and Razaque, M.A. (1986): Pulmonary paragonemiasis: Clinical features, diagnosis and treatment of 39 cases in Manipur. Trans. Royal Soc. Tropical Med. Hygiene, 80: 967-971.

Singh, T.N.; Kananbala, S. and Devi, K.S. (2005): Pleuropulmonaryparagonimiasis mimicking pulmonary tuberculosis: A report of three cases. Ind. J. Med. Microbiol., 23: 131-134.

Siti, N. MohdZain; Jerzy, Behnkes, M.; John and Lewis, W. (2012): Helminth communities from two urban rat populations in Kuala Lumpor, Malaysia. Parasite and Vector, 5: 47.

Soulsby, E.J.L. (1982): Helmithes, Arthropodes and Protozoa of domestic Animals. $7^{\text {th }}$ Ed. The English Language Book society and Baillers. Tindallschool.

Sun, T. (1988): Hymenolepiasis. Color atlas and textbook of diagnostic parasitology. IgakuShoin: pp. 285-286.

Tanaka, H.; Ohshima, S. and Fujinami, F.A. (1974): Survey of parasites in commercially available small laboratory mammals. Exp. Anim., 23: 15-30.

Tavarez, L.A.; Pend, F.; Placia, F.; Mendoza, H.R. and Polaco, D. (1991): Prevalence of protozoan in children with acute diarrheal disease. Arc. Domin, Pediatr., 27: 43-47.

Tesjaroen, S.; Chareonlarp, K.; Yoolek, A.; Mai-iam, W. and Lertlaituan, P. (1987): Fifth and sixth discoveries of Hymenolepis Diminutum in Thai people. J. Med. Assoc. Thail. 70: 49-50.

Tung, K.C.; Hsiao, F.C.; Yang, C.H.; Chou, C.C.; Lee, W.M.; Wang, K.S. and Lai, C.H. (2009): Surveillance of endoparasitic infection and the first report of Physalopetra sp. and Sarcocystic spp. In farm rodents and Japanese Society of Veterinary Science 71 (1):43.

Uchiyama, F.; Morimoto, Y. and Nawa, Y. (1999): Re-emergence of paragoniminasis in Kyushu, Japan. 1999. Southeast Asian J. Tropical Med. Public Health, 30: 686-691.

Udonsi, J.K. (1987): Endemic paragonimus infection in upper Igwun Basin, Nigeria: A preliminary report on a renwed outbreak. Ann. Tropical Med. Parasitol., 81: 57-62.

Uttah, E.C. Etim, S.E. and Ibe, D.C. (2013): Familial and occupational clustering of paragonemiasis in a Riverine community in eastern Nigeria. Trans. J. Sci. Technol., 3: 25-35.

Varghese, S.L.; Sudha, P.; Padmaja, P.; Jaiswal, P.K. and Kuruvilla, T. (1998): Hymenolepisdiminuta infestation in child. J. Commun. Dis. 30: 201-203.

Webster, J.P. and Macdonald, D.W. (1995): Cryptosporidiosis reservoir in wild brown rats (RattusNorvegicus) in the uk. Epidemiology and Infection 115, 207-209.

Wolfe, M. (1978): Oxyuris, Trichostrongylus and trichuris. Clin Gastroenterol Jani, 7: 201-217.

Wongjindanon, N.; Suksrichavalit, T.; Subsutti, W.; Sarachart, T.; Worapisuttiwong, U. and Norramatha, P. (2005): Current infection rate of Giardia lamblia in two provinces of Thailand. Southeast Asian J. Trop. Med. Public. Health., 36(suppl 4): 21-25.

WHO (1991): Basic laboratory methods in medical parasitology. Geneva, World Health Organization.

World Health Organization, (1997): Amoebiasis. WHO Weekly Epidemiology Records, 72: 97-100.

Yakubu, A.M. and Sathiakumar, N. (1985): The etiology of chronic childhood diarrhoea among Nigerian children. Journal of Diarrheal Diseases Research, 3(3): 145.

Zajac, A.M. and Conboy, G.A. (2006): Veterinary Clinical Parasitology. 7. Ames: Blackwell.

Zaki, A.M.; DuPont, H.L.; El Alamy M.A.; Arafa, R.R.; Amin, K.; Awad, M.M.; Assiouni, L.; Immam, I.; Z.; El Malih, G.S. and El Marsafi, A. (1986): The detection of enteropathogens in acute diarrhea in a family cohort population in rural Egypt. Am. J. Trop Med Hyg, 35: 1013-1022. 


\section{القوارض كمصدر محتمل لبعض الطفيليات المعوية المشتركة فى محافظة بني سويف \\ جيهان كمال اللبين عبل اللطبف ، لبليان ناجي محروس \\ Email: gehankamal2008@outlook.com Assiut University web-site: www.aun.edu.eg}

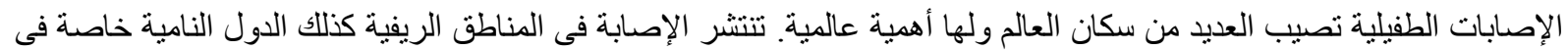

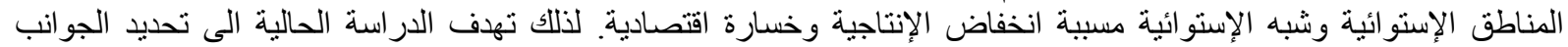

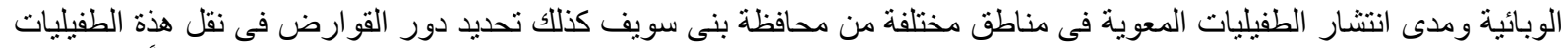

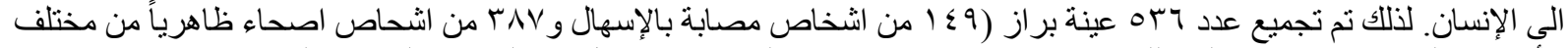

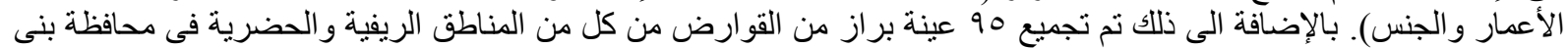

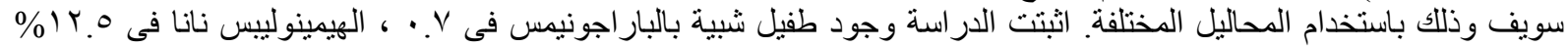

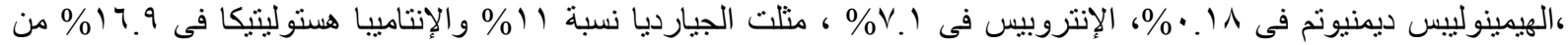

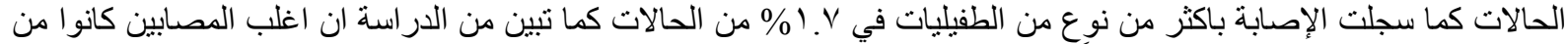

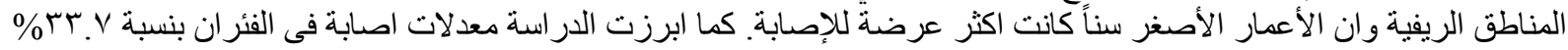

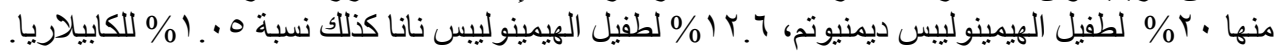

